\title{
ANALOGICAL REASONING (QIYĀS) AND THE COMMODIFICATION OF WOMEN: APPLYING COMMERCIAL CONCEPTS TO THE MARITAL RELATIONSHIP IN ISLAMIC LAW
}

\author{
Mohammad Omar Farooq ${ }^{*}$
}

\begin{abstract}
Analogical reasoning (qiyās) is one of the four sources of Islamic jurisprudence. It is recognised that the outcomes of qiyās are generally speculative in nature. However, a vast portion of the corpus of Islamic law is derived based on qiyās. One such area is marital relationship and mutual rights of the spouses. In several areas of marital relationship and mutual rights, the Islamic jurisprudents have applied concepts and tools that are related to commerce or business (tijārah). Such terminologies include bay' (exchange/buy/sale) and ijārah (lease). This article examines such employment of business-related framework in the area of marital relationship and mutual rights. Based on both classical and post-classical legal sources, the author analyses the legalistic tendency underlying the legacy of the traditional Islamic law, as exemplified in using business-related framework in an overreaching manner. This article also offers an explanation of how the traditional Islamic view on slavery might be closely connected to this commodified view. Furthermore, it sheds light on how such commodification can impact on family as a central social institution.
\end{abstract}

\section{Introduction}

Everywhere in the Muslim world there is an ongoing tension between the forces of rigid conservatism and those of modernity and reform. At the core of this tension is the corpus of Islamic law (fiqh). Many conscientious Muslims admit that much of the bulk of the corpus has become asynchronous with the spirit and vision of Islam on one hand and the contemporary challenges and realities on the other. ${ }^{1}$ Those countries proclaiming themselves to be 'Islamic' by instituting and implementing the traditional body of Islamic laws have found that even the common Muslim

* Mohammad Omar Farooq is the Head of the Center for Islamic Finance at the Bahrain Institute of Banking and Finance (BIBF). 
masses - otherwise deeply endeared to Islam - are experiencing difficulty coping with the laws' load of detail which is so often built on rigid or literal interpretation.

Accordingly, the Hudood Ordinance of Pakistan as part of the country's

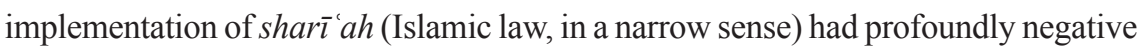
and unjust impact on many women. ${ }^{2}$ The Muslim women of India, on the other hand, have become so fed up with the All India Muslim Personal Law Board, an all male institution, that some ladies have taken the bold initiative of establishing their own All-India Muslim Women Personal Law Board. ${ }^{3}$ Meanwhile, Afghan society is just recovering from the Taliban regime that created a quite different, but still more profound, nightmare by, for example, obliging men to maintain their beards and women to completely shroud themselves in the traditional burqa, remain secluded at home and be deprived of any opportunity for serious work or study in the outside world. ${ }^{4}$

While such extremes cannot be generally attributed to the work of the noble jurisprudents and scholars from the classical period it must be recognised that by the time the various legal schools (madhhab) were formed and orthodoxy took shape within the first three to four centuries of its history ${ }^{5}$ Islam gradually fell victim to the effects of excessive legalism and literalism.

What is now commonly identified or understood to be representative of the shari 'ah, and which is commonly presented as something divinely sanctioned, is actually mostly composed of the interpretations of fallible human beings. This is so even though the human enterprise involved has been informed by the two primary Islamic sources, the Qur'ān and Sunnah - the Qur'ān constituting the direct, uncorrupted and infallible revelation of God, the Sunnah constituting the Prophetic hadith narrations relied upon to deduce much of the detail of the law and its codes. Although the scholars of hadìth have performed a most invaluable service by establishing the hadīth collections and developing methods for their authentication, individual ahädīth in themselves are generally neither divine nor infallible. Still more removed from a divine origin are the other two sources of Islamic law: ijmā' (consensus) and qiyās (analogical reasoning).

Muslim jurisprudence (figh), for the systematic deduction of law, developed a methodology of its own to interpret and make deductions in line with the shari 'ah, for example, qiyās (analogy), ijmā ' (consensus). [...] The basic 'ușūl are four: Qur'ān, Sunnah, ijmā ' and qiyās. The various schools of Muslim jurisprudence differ on the number of 'ușül to be used or emphasised, although all of them include the Qur'an and the Sunnah. ${ }^{6}$

The tendency to exaggerate the divine dimension of these secondary sources is rather entrenched. To increase the stature of each of these sources before the believers, the infallibility is often invoked directly or indirectly. 
The Qur'ān is the primary source of law. The other three sources, i.e., the Sunnah, ijmā and qiyās have been stamped with the revelatory character. [...] Qiyās derives its value from these sources; hence it is indirectly infallible. ${ }^{7}$

Ijm $\bar{a}^{\prime}$ has been the most important integrative tool used to establish the sanctity of the Islamic laws and codes, including those based on qiyass. However, there is precious little related to the doctrine of $i j m \bar{a}$ ' about which a consensus exists, which has been dealt with in detail in a separate work by this author. ${ }^{8}$ The focus of this article, however, is qiyās, the fourth source of Islamic fiqh.

Muslims desire to follow Islamic law because the corpus of law and its codes represent to them (they are told and taught this) the correct Islamic guidance for the entire spectrum of life. However, even though they want to follow Islam and the laws that are presented to them as constituting Islam, very few of them either know how these are arrived at or discern the justice and problem-solving capabilities this guidance embodies. Many Muslims now give the traditional body of Islamic law the cold shoulder and there are others who even like to disavow many aspects of it. The source of the bulk of the problem appears to be linked to the application of qiyās, as this otherwise neutral tool if applied with a legalistic bent of mind, without the desired sensitivity to the relevant issues at human level, can aggrandise human opinions to be wrongly perceived as divine rules.

The formalism and frequent use of qiyās in law generated hatred towards this principle. There was a widespread disagreement among the jurists, especially among the Iraqis, as a result of the use of ra'y [opinions] and qiyās. ${ }^{9}$

In many cases, when our Jurists confronted new situations, they successfully and effectively applied qiyās to seek new solutions. Muslims benefit from their precious and noble contributions in this regard. However, qiyās has been a mixed blessing. This article is focused on one particular example of misapplication of qiyās: applying commercial concepts to the marital relationship. This is illustrative of some of the key excesses arising from the application of qiyās when applied in a legalistic and literalist manner, delinked from the goals (maqāșid) and values of Islam. This is relevant not merely from the perspective of polemics or law, but particularly from the perspective of family as the central social institution. While Muslims are prone to criticise the condition of family in the West, and there are good reasons and foundations to do so, Muslims would be much better served to be self-critical and focus on the condition of family in Muslim societies so that the social tensions within can be identified and addressed and the institution can be upheld on the foundation of the pristine and balanced Islamic values. From a self-critical perspective, ${ }^{10}$ of especial importance are those legal views and positions that have not only shaped the orthodox Islamic laws but also the mindset. The issues related to family and 
gender relationship have become a major source of tension in the Muslim societies to the extent that this has exacerbated the religious vs. secular conflict and is pushing the younger generation in general and many women in particular to view Islam in an adverse way, when the problem might be in legal views and positions that are constructs of fallible human beings.

\section{Some Pertinent Basics of Qiyās}

Far from constituting a compendium of laws and codes, only a very small portion of the Qur'ān relates to specific guidance establishing what is permissible and what is prohibited. Beyond establishing some basic principles, norms and parameters the commonly accepted position of Islamic fiqh is that except what is categorically prohibited the default guidance of the Qur'ān is permissibility. ${ }^{11}$

As the Prophet's life, reflected in his words and actions, is a model, Muslims turn to the Sunnah (authenticated by hadīth) for detailed guidance. Yet, neither the Qur'ān nor the Sunnah/hadīth covers every situation that its adherents might encounter. This is where qiyass or analogical reasoning - where "the root meaning of the word [...] 'measuring', 'accord', and 'equality""12 - makes an appearance.

Qiyās was meant to seek similarity between new situations and early practices, especially those of the Prophet. ${ }^{13}$

[...] no one at all should [give an opinion] on a specific matter by merely saying: It is permitted or prohibited, unless he is certain of [legal] knowledge, and this knowledge must be based on the Qur'ān and the Sunnah, or [derived] from ijmā ' (consensus) and qiyās (analogy)..$^{14}$

Gradually, qiyās gained greater importance and assumed a more central role:

Qiyās was recognised as a fourth source of law along with the other three sources. By and by, people began to depend on it extensively. Ultimately it overreached the Qur'ān and the Sunnah. ${ }^{15}$

Some people suggest while others claim that there was an ijmā' among the companions about the validity of qiyās as part of the Muslims' toolkit to arrive at or deduce solutions involving situations that are not covered by the other primary sources, i.e., the Qur'ān and the Sunnah.

The companions were unanimously in agreement concerning the application of analogy. ${ }^{16}$

However, those reasonably familiar with $i j m \bar{a}$ ' as a doctrine and a method, ${ }^{17}$ know that this claim of companions' consensus concerning qiyās is simply untenable. It can be argued that many of the companions applied what they knew to situations that were unknown yet similar to prior established positions, and thus in this way 
what they practised amounted to qiyās. However, to claim that the companions of the Prophet knew this constituted qiyās, deliberated accordingly and reached a consensus thereafter is difficult to find evidence for.

Indeed, those who want to establish the validity of everything using a text-oriented or text-bound ${ }^{18}$ approach, through the identification and proffering of textual evidence, have tried to provide the relevant evidence from the Qur'ān and Sunnah as the basis for qiyās as one of the sources of Islamic fiqh. ${ }^{19}$ There is no verse in the Qur'ān that the scholars have been able to agree upon which can be clearly discerned as acting as the basis of qiyās. Furthermore, the Sunnah, through the Hadith collections, has been offered to establish additional textual justification for qiyās. Once again, there is no agreed-upon basis even though plenty of different examples abound which have been offered by different scholars.

Some Muslim scholars and groups, one such represented by the Zāhirī school and its main protagonist Ibn Ḥazm (d. 1064), have rejected qiyās altogether. Ibn Ḥazm's Zāhirī approach is based on literalism and development of the explicit meaning of the textual evidences while shunning qiyās. Nevertheless, there have been repeated attempts to justify qiy $\bar{a}$ s as being part of $i j t i h \bar{a} d$, an often-quoted hadīth is narrated by $\mathrm{Mu}$ 'àdh b. Jabal, who was sent to Yemen by the Prophet. According to the hadīth, when the Prophet asked Mu'ādh how he would judge a situation that was not directly addressed in the Qur'ān or Sunnah, he replied: "I shall do my best to form an opinion and I shall spare no effort." ${ }^{20}$ Ibn Zāhirī , as well as some scholars from other persuasions, dispute this hadīth. ${ }^{21}$

Careful readers might be surprised when they stumble upon the chapter headings in none other than Sahih al-Bukhari which state: "What is said against judging (in religion) made on the basis of one's own opinion (i.e., ra'y) or by qiyās" or "Whenever the Prophet was asked about something regarding which no verse was revealed, he would either say, 'I don't know' or give no reply, but he never gave a verdict based on opinion or on qiyās." ${ }^{22}$ In actual fact, at one stage, the opposition to $r a^{\prime} y$ or qiyās was so strong that the chapter headings reflected Imām al-Bukhārī's juristic view on this issue. ${ }^{23}$

Regardless of the opposition and disagreement among themselves the four traditional schools, representing the mainstream, helped qiyās to emerge and serve as one of the predominant and most commonly employed tools of Islamic jurisprudence.

The relationship between ijmā' and qiyās is a close one. While ijtihād ensures that Islamic jurisprudence is dynamic, it is the institution of qiy $\bar{a}$ s that has brought discipline to the general application of human reasoning to determine what is islamically acceptable as opposed to what is not concerning things or situations that have not already been covered by the other three sources. However, for the result of an analogical deduction (qiy ās) to be broadly accepted, it also has to be 
validated by $i j m \bar{a}$ ? When validated, most Muslim scholars have placed a high value on qiy $\bar{a} s$ as a methodology.

- The procedure of analogy is devised to eliminate the free use of reason and independent value judgments; ${ }^{24}$

- there is an acute controversy among the classical jurists over the validity of ijma $\bar{a}^{\prime}$ on questions based on analogy (qiy $\left.\bar{a} s\right)$ and individual interpretation $\left(\right.$ ijtihād) ${ }^{25}$

- $i j m \bar{a}$ ' has the authority to decide whether a certain opinion of the Jurist or a decision of a Judge is right or wrong. No qiyās can attain the status of law unless it is authenticated by ijmā ${ }^{\cdot 26}$

\section{Diversity of Views about Qiyās}

Even though those who follow the four main Sunni schools of thought generally accept qiyās as one of the four sources of Islamic jurisprudence there is considerable disagreement about what qiyās constitutes, its scope, the method of its validation and so on.

After the Companions, jurists differed over the extent to which analogy could be relied upon. [...] The question of analogy has caused a good deal of controversy. ${ }^{27}$

As per many aspects of Islamic jurisprudence little consensus exists concerning qiyās. Each school prefers its own definition, possessing its own special emphasis or nuance..$^{28}$

The common denominator in all these cases involves identifying the illah (effective cause of the law; ratio decidendi). "It appears that the term 'illah (effective cause) did not come into use in juristic reasoning up to the time of al-Shāfi ' 1 (d. 820). It is not also traceable in the writings of the early schools of law. Al-Shāfi ' $\overline{1}$ terms the common factor sometimes ma 'na (idea) and at other times aṣl (basis). The term 'illah must have been employed in the post- Shāfi 'i period.” ${ }^{29}$ Important differences in this regard are also notable. For al-Shāfi '⿳亠丷, qiyās and ijtihād are synonymous, while for other scholars this is not the case.

Just as the consensus that qiyās constitutes a valid methodology of Islamic jurisprudence does not exist, so there are similar problems concerning the consensus over what constitutes an 'illah, how it is derived, and even how it is validated. ${ }^{30}$

In reaching conclusions about the unknown starting from the known, extending the frontiers of human knowledge and understanding to new situations, or in the derivation of solutions to problems not encountered previously, analogy is the most commonly employed tool of man's reasoning. ${ }^{31}$ 
Analogical reasoning has been quite useful in many scientific discoveries. ${ }^{32}$ It is no surprise that the use of analogical reasoning is widespread in modern education and the GRE test for graduate admission in the United States includes problems based on analogy. ${ }^{33}$

Thus, the fascination with and the extensive use of qiyās by Muslim scholars is easily understandable and only natural. In a religious context though, an otherwise common tool of human reasoning takes on a sacred character. Regardless, it is important to bear in mind that qiyās is essentially speculative (zannī). ${ }^{34}$

The problem with qiyās as a source methodology and authority in Islamic jurisprudence is that it is seriously compounded by a lack of agreement concerning the relationship between the așl (the original case) and the validity of qiyās-based rules so derived. ${ }^{35}$

Essentially then, qiyās constitutes a speculative proof as it is based on fallible human reasoning. However, when infallible divine sources and fallible temporal sources become part of a single toolkit, unless an appropriate level of conscious humility regarding human fallibility is taken into due consideration and explicitly acknowledged, excesses can occur. In the following sections, examples are dealt with whereby reputable Muslim scholars and jurisprudents have become carried away in the literal and legalistic application of qiyās.

Before delving into our substantive analysis of qiy ās, let us begin with a frivolous example of general deductions. Alauya is an Islamic jurisconsult in the Philippines and a member of the country's Sharì 'ah Bar. In explaining 'ibärah, one of the methods of deducing argument (istidlāl) from the Qur'ān, he writes in his book Fundamentals of Islamic Jurisprudence:

Ibara, or the plain sentence. Example "Mothers, after they are divorced, shall give suck unto their children for two whole years, if the father desires to complete the term, who is obliged to maintain and cloth them according to that which is reasonable" (Qur'an 2:233). From this verse, two deductions are made. First, the mothers are entitled to support, while breastfeeding children even though they are divorced. Second, the duty of supporting the breastfeeding mother is incumbent upon the father. This shows that the relationship of the child is closer with the father than with the mother. ${ }^{36}$

The second deduction earns some critical comments. If the father supports the mother is the basis for deducing that the child is closer to the father then whenever poor people (fathers or mothers with children) are supported by a government welfare programme, it could also be argued that the government is closer to the child than either the mother or the father. Does that make sense?

In analysing these problematic matters, it is not to be inferred that the Muslim scholars and jurists had a negative intent, merely that, as they were pious, conscientious, and brilliant, they were also fallible. They developed many of the 
details concerning Islamic fiqh and offered their reasoning with an obvious zeal such that they became carried away, not stopping to consider or anticipate possible future ramifications of their pronouncements. Many acted as trailblazers during their own time, never hesitating to cast as critical an eye as possible at the corpus of Islamic law that preceded them in order to improve it in whatever way they could. This does not mean, however, that they always succeeded in doing so.

\section{Some Problematic Issues in Application of Qiyās}

Since qiyās was one of the most commonly employed tools of Islamic jurisprudence, finding relevant examples whereby the scholars and jurists have become carried away is not difficult. However, in this article our focus is on commodification of women that has occurred in traditional Islamic fiqh through application of commercial concepts to marital relationships.

\section{Marriage, Contract and Sale}

Marriage is the core of all social institutions. In some societies and religions, such as Christianity, marriage is a sacrament (i.e. "a rite which removes the taboo on sexual intercourse between a man and a woman, while at the same time imposing a lifelong taboo on the intercourse of either of them with a third party") $)^{37}$ by which it is made so sacred that traditionally it could not be dissolved. This is why the Roman Catholic Church considers divorce as one of the greatest sins and as such, effectively, prohibited. On the other hand, in many modern, secular societies, marriage represents no more than a contract, and thus no permanence or sanctity is attached to it. Indeed, the direction of these societies is such that even marriage is not legally required for the union of two people. Living together without marriage, having children out of wedlock, even marriage within the same sex, are all being accommodated or legalised in the present secular times. Marriage in Islam is neither sacramental nor is it merely a contract.

The distinction between sacred and secular was never explicit in Islam. Any action or transaction has religious implications. Legitimate sex is not defined as evil. Women, at least in doctrine, are not held inferior to men on the spiritual level, since they are not thought of as 'guilty' of any offenses from which men were, or are, free and immune. Moreover, marriage in Islam was not conditional on officiation by a priest because, strictly speaking, there was no such office. Neither was religious benediction, though highly recommended for the occasion, a necessary requisite for the validity of the marriage.... [Thus] 'marriage is a contract, but it is also a covenant. ${ }^{138}$

However, it appears that legalistic tendencies, which have become dominant in the general practice of Islamic law, have caused marriage to be viewed with

ICR 3.1 Produced and distributed by Pluto Journals ICR.plutojournals.org 
an overwhelming bias toward the contractual dimensions involved. From the dowry to maintenance, from marital obligations to the conditions of divorce and its procedures, the emphasis is focused on contractual aspects rendering marriage a totally formalistic experience.

In Muslim societies, marriage is not so much a sacrament as a contract regulated by a code of law rooted in religious precepts - in the shari'a. [...] It is based on a strong patriarchal ethos imbued with religious ideas and ethics. This ethos defines marriage as a contract of exchange, whose prime purpose is to render sexual relations between a man and women licit. Any sexual contact outside this contract constitutes the crime of zina, and is subject to punishment. The marriage contract is patterned after the contract of sale and its essential elements are (i) the offer (ijab), [...] (ii) its acceptance (qabul), [...] and (iii) the payment of dower (mahr), which is a sum of money or any valuable that the husband pays or pledges to pay the wife [...] The contract establishes neither the commonality in matrimonial resources nor equality in rights and obligations between spouses. ${ }^{39}$

The idea of a dowry (from the bridegroom to the bride) is not unique to Islam. Indeed, in various societies and cultures, and throughout history, it has been present. Al-Ati provides a detailed exposition of various economic and other modern theories to explain the custom surrounding the dowry. However, his analysis shows that none of these concepts help explain and render an understanding of the Islamic position concerning the subject. ${ }^{40}$

While Islam has mandated the provision of a mahr it has not set any minimum or maximum and neither has it specified its exact form. This is an important notion to grasp when attempting to understand the inability of most theories to explain the Islamic position concerning the mahr. ${ }^{41}$

The theory that the dowry is compensation to the father or his substitute for the loss of the girl's economic service is inapplicable for the primary reason that the dowry can be such a nominal value that it would hardly be considered proper compensation to the guardian concerned. In addition, Islam mandates that the mahr belongs exclusively to the bride. The dowry cannot be claimed or usurped by anyone else, including the bride's parents or any other guardians. ${ }^{42}$

There are also theories that the dowry (from bridegroom to bride) serves "as an obstacle to the dissolution of the union for frivolous reason" or that "it worked as a deterrent to polygamy". ${ }^{43}$ However, these theories do not hold for most marriages in Muslim societies, where a dowry is not really significant enough to serve the said purpose.

What of the religious explanations by the Muslim scholars and jurists then?

Muslim jurists of later centuries have held the technical view that dowry is enjoined in return for the man's right, at least potentially, to have legitimate access to cohabitation 
with the woman in question. She is entitled to dowry because she has consented to marriage and made herself accessible. Much discussion among the jurists has centered on this issue. But the exponents of this view appear to assume or to infer that women have no sexual desires and needs of their own, that gratification is not reciprocal, that sex is a cheap commodity in view of the permissibility of nominal dowries, and that marriage is little more than a commercial transaction. That list of assumptions and inferences may be extended. Yet, these seem contrary to the bio-psychological facts and to the very idea of marriage which is depicted in the Qur'an (e.g., 30:21) as a shelter of peace and comfort, and as a means of mutual love and mercy. ${ }^{44}$

There are no established data concerning the number of Muslims who contract their marriage where the marrying parties think they are involved in a commercial transaction: the bridegroom thinking that he is involved in a purchase and the bride believing that she is involved in a sale. Even without the information gathered from scientific surveys or more extensive study of the subject it can be safely assumed that most women would be nauseated and repulsed at the thought of marriage constituting their sale and purchase. Moreover, men too would consider the idea of any kind of commercial transaction regarding marriage quite repugnant.

Unfortunately, on reading the legalistic works and positions of the Muslim jurists one cannot but be left with the distinct impression that they have indeed reduced marriage to a commercial transaction. Let's first take the viewpoint from Hanafì sources.

A woman may refuse to admit her husband to a carnal connection until she has received her dower ${ }^{45}$ of him, so as that her right may be maintained to the return, in the same manner as that of her husband to the object for which the return is given, as in sale. ${ }^{46}$

What is here advanced proceeds upon a supposition of the whole dower, or a certain portion of it, being Moajil, or prompt; but if the whole be Mowjil, or deferred, the woman is not at liberty to refuse the embraces of her husband, as she has dropped her right by agreeing to make her dower Mowjil, - the same as in the case of sale, where, if the price of the article sold be made deferrable, the seller is not at liberty to detain the article sold on account of the price. ${ }^{47}$

It is proper to observe, that where the woman refuses to admit the husband to a repetition of the carnal act, as above stated, yet she has, nevertheless, (according to Haneefa) a claim to her subsistence, as her refusal does not, in any case, proceed from any stubbornness or disobedience, since it is not exerted in resistance to a right, but rather in maintenance of one. - The two disciples hold that she is not entitled to any subsistence; - and their argument on this occasion is, that the sole object of the contract has been duly delivered to the husband, either by the single carnal act, or by the single complete retirement, 
as aforesaid; on which account it is that her right to her whole dower is confirmed and established, and consequently no right of further detention of her person remains with her; as in a case of sale, where the seller having delivered the article sold to the purchaser, before receiving the price, has no further right over it. ${ }^{48}$

If a man marries two women by one contract, one of whom is lawful to him, and the other prohibited, his marriage with the one who is lawful holds good, but that with the other is void, because in that only a cause of nullity is found: contrary to where a man puts together a freeman and a slave, and sells them by one agreement, as such sale is null with respect to both, because sale is rendered null by invalid condition, and the consent to the contract of sale is required with respect to the free person, in order to the legality of it with respect to slaves. ${ }^{49}$

In applying commercial concepts to marital relationship, other schools are remarkably similar. The Mālikī position is articulated even more vividly in one of the most authoritative compendia of Mālikī law. Under the general section of "Sickness" and sub-section "Serious illness precludes marriage, but the dowry is paid from the third", it is mentioned:

It is not permitted for a man with a very serious illness to get married but if he does get married and consummates the marriage, then his bride's dowry is the first thing to be paid from the third of his wealth he is permitted to leave as he wills. [Or for a sick woman which may prove fatal. That is because he is restricted in respect of his property and it is connected to all who has a lien on it absolutely.... $]^{50}$

\section{Competition between Suitors}

No one should propose marriage to a woman if another proposal has already been accepted, nor should anyone try to outbid his brother, if an agreement has already been reached. [According to what al-Fakhani said, "The expression means a prohibition." This is to propose when there is an outstanding proposal and to bid when there is an outstanding bid provided an agreement has been reached between the couple of the parties to the bid. In respect of marriage, this means that the couple incline to one another so that only the offer and its acceptance remain. In the sale it is a precondition that the money be weighed, for instance, and the goods free of faults. If he sees a fault, he can return it. $]^{51}$

Marriage contracts containing uncertainty as is any marriage involving uncertainty (gharar) in either the terms of the contract or the amount of the dowry or any marriage in which the dowry includes anything whose sale is forbidden. ${ }^{52}$

The following excerpt, taken from one of the most authoritative compendia of Shäfi 'i fiqh should give a clear idea about the Shāfi î̀ school. 
The Integrals of a Marriage Agreement [...]: The Spoken Form:

The first integral is the explicitly stated spoken form (O: comprising a spoken offer by the guardian and its acceptance by the groom, like other, nonmarital transactions. Its necessary conditions are the same as those of valid sale..$^{53}$

The Hanbali view is reflected in the following:

Al-Khiraqi's three principles on khul' are repeated verbatim in the post-classical Sunni corpus of the erudite Hanbali legist, Muwaffaq al-Din Ibn Qudama (d. 1223), with further specification that "separation ( $k h u l$ ') does not require action by a judge: this is the position of Ahmad [b. Hanbal, school founder, d. 840],... and also that of Malik, Al-Shafi'i and the party of opinion (ahlal-ra'y; the Hanafis) [...] Since it is a transaction (exchange; mu'awada), similar to a sale or a marriage contract, it does not require a judge, and also because it is dissolution of contract by mutual consent (qat 'aqd bil taradi)." ${ }^{54}$

This article has generally focused on Sunni schools of jurisprudence. However, Shia jurisprudence, somewhat ambivalent about qiyās,${ }^{55}$ might not be much different, or even worse, in this regard, especially in light of their vigorous defence of mut'a (temporary marriage), which is modelled after bai' (sale/purchase).

Unlike a permanent marriage, which has several other objectives, the sole objective of mut'a marriage is istinta' (enjoyment), Tusi argues. According to him, temporary marriage (mut'a) is contract for a specific purpose, in which remuneration (ajr) is paid; hence, there is no mahr or inheritance. Marriage ends at the appointed term; no talaq is pronounced. Mut'a is modeled on a sale contract in which the payment of consideration money and specification of the duration of time are essential conditions. ${ }^{56}$

So, how precisely did the jurists draw this connection between marriage and 'sale'? The answer lies with qiyās. Marriage is a form of contract, as is sale and purchase (commercial transactions or exchanges). Therefore, in enforcing the right of the husband to have his wife in his bed, in denying maintenance to her when she refuses to share it with him, or in determining the conditions pursuant to a lawful/valid and unlawful/invalid marriage, the jurists have identified a tremendous analogical parallel between marriage and commercial transactions.

It is interesting to note that the term mahr (bride price), which usually connotes commercialisation of marriage, is not used in the Qur'an at all. It occurs very infrequently in the Traditions of the Prophet; when it does, it is usually accompanied by other terms such as faridah (God-given right), or sadaq (which is connected with a root word meaning marriage-gift, charity, friendship, fidelity, truth, etc.). The jurists have used these terms interchangeably as denoting the God-given right of dowry. But it is not certain whether in these interchangeable usages the traditional connotations of the term mahr were sublimated to the moral and charitable denotations of terms like sadaq, faridah, and so 
on; or whether these terms themselves took on the traditional connotations of mahr. A review of the classical legal texts would seem to indicate that where it occurs, the term mahr is used in a sublime moral sense indistinguishable from the meaning of sadaq, faridah, and similar terms. But the law books and usages of subsequent centuries seem to use mahr and other alternate terms in a sense very much akin to the traditional meaning of bride-price. This reversal of meaning was apparently correlated with a decline in juristic creativity and the status of women and also with a misconception of the idea of marriage. ${ }^{57}$

Neither the theories offered by social scientists nor the ones underlying the views of the Muslim jurists help in providing a proper understanding and appreciation of the role of the mahr in Islam. Acknowledging the need for further exploration, Al-Ati offers some suggestions that are quite relevant and meaningful:

Dowry is probably a symbolic expression of the groom's cognizance of the economic responsibilities of marriage and of his readiness to discharge all such responsibilities subsequent to marriage. It may be thought of as a manifest assurance on his part that the bride's economic security and rights will be maintained. It is a symbolic acknowledgment that he does or will dissociate the purpose of marriage from the designs of economic exploitations. For 'instinctive' or cultural reasons, it is usually the women who need reassurance of the man's intentions and interest. This reassurance may require more than verbal expressions of love and seriousness on the man's part, and dowry may be the tangible symbol of such love and seriousness. To the bride, it is a token of the groom's desire to enter into a union with her. To her family, it is a gesture of mutual friendship and solidarity, an assurance that their daughter will be secure and in good hands. However, there may be other symbolic meanings of dowry, as has been mentioned earlier. Nor is it to be overlooked that what is being suggested here is conceptualised in terms of the religious and moral ideals which may or may not be in fact fully implemented. There is no sufficient ground to assume that the actual has always coincided with the ideal in this case. ${ }^{58}$

\section{Marriage, Contract, and Lease}

The focus of the preceding section was to demonstrate how, under the influence of legalism and literalism, the scholars sometimes became carried away in their application of qiyās. Inferring an analogical connection between contracts and sales and then applying it to marriage is hardly appropriate. However, there are other related issues that are also worth mentioning.

Certain aspects of Islamic law are simply impractical while others are unfair. For example, the traditional schools require that as part of the marriage the wife be entitled to her own, exclusive dwelling. 
It is incumbent upon a husband to provide a separate apartment for his wife's habitation, to be solely and exclusively appropriated to her use, so as that none of the husband's family, or others, may enter without her permission and desire, because this is essentially necessary to her, and is therefore her due the same as maintenance, the word of God appoints her a dwelling house as well as a subsistence: and as it is incumbent upon a husband to provide a habitation for his wife, so he is not at liberty to admit any person to a share in it, as this would be injurious to her, by endangering her property, and obstructing her enjoyment of his society...59

A wife is entitled to lodging in a house unoccupied by members of the husband's family. ${ }^{60}$

Thank God the scholars did not explicitly require every Muslim to be rich or at the very least, well-to-do, because the economic condition of the Muslim world is such that the vast majority survives merely with just one roof over the entire family instead of inhabiting separate rooms, let alone an exclusive room just for the wife. Interestingly, women hardly know about this grand right of theirs and, understandably, there is little effort on the part of the Muslim scholars to educate them about this privilege and of the requirement of men to honour it. It is notable that there is no authentic or explicit textual evidence to offer the specified right to an exclusive dwelling for the wife, even though it can be safely asserted that Muslim wives would be deeply gratified by having this right honoured.

However, lest Muslim women get carried away after learning and then insisting on exercising such a valuable right, legalism and literalism have pervaded many of the laws derived in the name of Islam and there are bound to be plenty of other surprises in store for them as well. Assigning an exclusive dwelling does not mean that the wife owns it. In actual practice, the husband has far-reaching control over the situation.

A husband is at liberty to prevent his wife's parents, or other relations, or her children by former marriage, from coming in to her, as her apartment or habitation is his property, which he may lawfully prevent any person from entering; but he cannot prevent them from seeing and conversing with her whenever they please... Some have said that he cannot prohibit them from coming in to her, any more from conversing with or seeing her. ${ }^{61}$

Just as the assignment of an exclusive dwelling for the wife is a pleasant surprise to most women (and is possibly shocking to most men), there are also some unpleasant surprises for women too. According to Islamic law, wives are entitled to certain maintenance (nafaqah). But what precisely does this consist of?

When a woman surrenders herself into the custody of her husband, it is incumbent upon him thenceforth to supply her with food, clothing, and lodging, whether she be a Muslim or an infidel, because such is the precept both in the Koran and in the traditions [...]. ${ }^{62}$ 
Nafaqa literally means that which a man spends over his children; in law it means feeding, clothing and lodging; in common use it signifies food. ${ }^{63}$

What if the wife becomes sick, especially on a long-term or even permanent basis? In this eventuality, the law is very clear; the wife is legally entitled only to food, clothing and lodging. Conspicuously, there is no specific or detailed textual evidence to support so narrow a definition of maintenance. Most Muslim men and women might be shocked to learn that Islamic law does not stipulate that the husband should take care of his sick wife and that she is not entitled to maintenance (food, clothing, lodging), especially when she cannot fulfil the primary basis of the marriage contract: to be able to carnally satisfy the husband.

If a woman falls sick in her husband's house, she is still entitled to a maintenance. This is upon a principle of benevolence, as analogy would suggest that she is not entitled to maintenance, where she falls sick so far as to be incapable of admitting her husband to the conjugal embrace, since in this case she cannot be deemed in custody for the purpose of enjoyment. ${ }^{64}$

Even though there are contrary opinions, this is not simply another example of the misapplication of qiyass, but the complete marginalisation of the fundamental values of Islam. Once again this demonstrates the legalistic and literalist propensity to which the law has fallen victim. In a section "Maintenance in Sickness", Al-Ati further elaborates:

The Qur'an and the Sunnah have enjoined care for and kindness to the wife. Yet the application of this general principle to the case of a sick wife has stimulated curious arguments, differences of opinion, and legal niceties. According to some jurists, a sick wife who, on account of her failing health, is unable to discharge her marital duties has no legal right to maintenance by the husband. ${ }^{65}$

The problem of maintenance of a sick wife is provocative, although it seems more apparent than real, that is, more of an academic exercise than a practical issue. It probably indicates that the later in time, the farther some jurists drifted away from the spirit of the law and its ethical foundations. It is curious that neither the Qur'an nor the Sunnah raised the problem in any way that can be likened to the approach of those jurists. Moreover, none of the disputants produces any authoritative evidence in support of his argument against the adversaries. ${ }^{66}$

Al-Ati writes that this tendency is not confined to maintenance only, according to the majority of jurists, sick wives are not entitled to the cost of their medical care as well. So, on what basis do the jurists, generally speaking, deny the medical costs and maintenance due to a husband's wife? The answer lies, once again, with qiyās. 
Related to the problem of a sick wife's maintenance is the cost of her medical care. The formal consensus, not the unanimous opinion, of the majority of the jurists is that the husband is not legally responsible for the cost of medicine, the physician's fee, etc. Some jurists, however, maintain that if the husband is financially comfortable and the cost of medical care is modest, he is responsible for it. Others argue that even if he is not legally responsible for the cost, it is still his religious duty to bear the responsibility out of compassion, courtesy, or in conformity with the social norms. Those who exempt the husband from the responsibility do not consider the cost of medical care to be part of the obligatory maintenance. They draw an analogy between wifedom and leased property; tenants are not responsible for the repairs and improvement of the premises. Their obligation is to pay only the rent; the rest is the owner's charge. Like a tenant, a husband is not responsible for the cost of any treatment his wife may undergo to restore or improve her health. ${ }^{67}$

The culprit here is clearly the overzealous application of qiyās. The qur'ānic commandment to abstain from all activities when the call for the Friday prayer has been made demonstrates one example of how qiyās has been extended to cover all aspects of marital life.

Sale of goods, or conducting business, during the time of the Friday congregational prayer is prohibited by the following verse of the Qur'an: "O you who believe! When the call is proclaimed to prayer on Friday, hasten earnestly to the remembrance of God, and leave off sales transactions." The 'illah of this prohibition is that which, from the transaction of sale, detains one from proceeding to the Friday prayer and the potentiality of alienating one from the Friday prayer. This 'illah has been deemed to be present in the transactions of lease, of mortgage, and of marriage. Therefore, the hukm upon these transactions during the Friday prayer is the same as that of sale. ${ }^{68}$

That many women are turning against these types of 'orthodox' Islamic laws, while they still feel attached to the Islam that is embodied in the Qur'ān and the Sunnah, is an established phenomenon. Many Muslim men also find much of the detail of the law in question, especially those aspects derived using the all too fallible methodology of human reasoning (qiyās), asynchronous with Islam itself. Contemporary Muslim scholars, especially those not trained and indoctrinated in the orthodox tradition, are also challenging this legalism.

[C]ontemporary Muslim scholars are impatient with these formalistic interpretations of the law which, on the one hand, enjoin the husband to furnish with maids - an obvious luxury - but, on the other, exempt him from the responsibility for her medical care. For these scholars, this is plain mockery, casuistry, and abuse of the purposes of the law.

Moreover, such formal interpretations contain no authoritative evidence. Nor do they seem compatible with the ordinances of the Qur'an and the Sunnah, which unequivocally 
call for kindness, compassion, and consideration. Here again, the question arises: were these jurists fighting windmills or tackling a real problem? How could they overlook the strong directives of the Qur'an and the Sunnah, and focus, instead on such a formalistic approach?

The view that a husband may be exempted from the obligation of maintenance and payment for an indisposed wife's medical care cannot be explained in terms of any authoritative text from the Qur'an or the Traditions. Not only is there no such possible explanation, but also the very view is perhaps one of the clearest instances of 'deviation' from the orientation of the basic sources of Islamic law. ${ }^{69}$

It is important to understand that the misapplication of qiyās is not an isolated occurrence. Al-Ati offers some insight into the direction that juristic works have taken over the centuries:

Aside from the possibility of intellectualistic riddles or formal casuistries, this view, together with the accompanying analogy between wifedom and 'leased property' was probably a reflection of certain social and intellectual trends....

The demographic composition of the Muslim population was growing diverse as well as complex. An urban life style on a new large scale, with the concomitant relative anonymity and individuality, was increasingly in vogue. Under such circumstances, marital bonds would be regarded not so much as alliances of families, clans, or tribes or as "companionship" ties as individual 'contracts' largely oriented to specific formal exchanges of service. Women, as a rule, became increasingly secluded in the background and excluded from the world of men.... With the traditional mother role so depreciated, and with the companion role so contested by other rivals, probably little was left for the normal housewife other than being an object of sexuality. Even that role was not confined to her exclusively. ${ }^{70}$

The legal treatises reflect the tendency toward the "seclusion of women" from active life in their works. When marrying, does the wife regard and the husband expect that she should 'surrender' to the "custody" of her spouse? Or, is there any woman who expects that marriage basically entails her embracing a life of 'confinement' and 'seclusion'? This, unfortunately, is the way the jurists understood marriage and how they presented it in their legal interpretations.

When a woman surrenders herself into the custody of her husband, it is incumbent upon him thenceforth to supply her with food, clothing, and lodging, whether she be a Muslim or an infidel, because such is the precept both in the Koran and in the traditions; and also, because maintenance is a recompense for the matrimonial restraint. ${ }^{71}$ 
The pertinent Arabic word is ahbas, derived from habasa (meaning: to block, detain, imprison). ${ }^{72}$ This characterisation, in the translation of Haskafi's Durr al-mukhtār, is still more explicit and vivid:

[M] aintenance is compensation for her confinement. ${ }^{73}$

Contrary to the legacy of the Prophetic period, as women became secluded in society and as they became 'confined' by juristic opinion Islamic legal discourse became isolated from and mired in legalism and literalism.

\section{Exploring Some Relevant Aspects of the Jurists' Resorting to Sales Contract}

\section{Was Invoking Sales Contracts in Case of Marriage Contracts Necessary?}

A relevant question in this context is whether there was any compelling or suitable reason for resorting to sales contracts for marital relationship. To understand this question, it is important to note that while the theory of contract ('aqd) in Islamic jurisprudence covers broad aspects of life, including commerce and marriage, essentially there is no separate framework for marriage contracts that is distinct from commercial contracts.

The Islamic marriage contract is a variant of Islamic contracts... Unfortunately, little attention has been given to the study of Islamic contract theory, which arose originally in the commercial context..$^{74}$

For apart from particulars concerning the subject matter, there is not a great deal of difference among marriage contracts, agreements creating partnerships, claims for debts, or deeds of sale [...] It should be pointed out, in fact, that sale is usually considered the typical contract in Islamic law, after which other contracts are patterned. Islamic law never developed a general theory of contracts. ${ }^{75}$

Lacking a separate or distinctive framework, and for a very special reason, which is discussed below, the jurists did not feel it necessary to consider the need for a separate or sub-theory of contract for marital relationship.

However, while they should not have framed the marriage contracts on the basis of sales contracts, the fact of the matter is that they did not really need to do so either. The marriage contract as a subset of contract has some distinct parameters (discussed below) that makes it distinct from sales or commercial contracts. The rights and responsibilities in the context of a relationship that is not merely contractual but also covenantal could have been independently developed or identified on the basis of reciprocity and promise/commitment without any reference to commercial or sales contract. 


\section{Why Did the Jurists Resort to Sales Contracts that Ended Up Commodifying Women?}

Invoking sales contract may not have been necessary (and, of course, it was undesirable), it is worth exploring why the noble scholars of Islam felt comfortable framing the women's rights and responsibilities in the marital context in terms of bay '(sales). One possible explanation is that this becomes a non-issue, once human beings are commodified. There have been scholars who could not think about women except in terms of 'commodity'. Interestingly, in a hadìth, the Prophet Muhammad said: “al-dunya mata'wa khairu mata'id dunya al-mar'atu as-salihah". ${ }^{76}$

The Arabic word mata' has a broad range of meaning: enjoyment, pleasure, delight, gratification; object of delight; necessities of life; chattel, possession, property; goods, wares, commodities, merchandise; furniture; implements, utensils, baggage, luggage, equipment, etc. ${ }^{77}$ However, just because all these words are covered by the original word in Arabic, it does not mean that we can arbitrarily or randomly choose any word as an appropriate equivalent in English. Interestingly, while many scholars have translated and understood mata' as delight or provision, some scholars have not hesitated to translate it as "commodity": "The world, the whole of it, is a commodity and the best of the commodities of the world is a virtuous wife." ${ }^{78}$ Others have translated it as 'provision'. ${ }^{79}$

Why does anyone then choose commodity in this context, where there are other relevant and more nuanced meanings available? There might be a deeper cause.

In pre-Islamic [i.e. pagan] Arab societies, women were bought and sold as commodity. Islam by giving women the right to decide who to marry, and have a part in the marriage contract, elevated her status from that of a commodity to that of an equal partner in the marriage institution. ${ }^{80}$

Well, this should be true about Islam, but unfortunately Muslims did not quite give up the notion of women as commodity, because Muslim scholars did not reject and abandon the idea of the human being as a commodity. How can that be?

A pertinent question here is: what is common between marriage and a sale? Qiyās is based on 'illah (ratio decidendi or underlying criteria) being contractual agreement involving two parties. This is correct. However, what is the difference between marriage and sale? It is in determining, establishing and recognising a fundamental difference between the two, in my humble submission, that the orthodox position has failed to properly draw the boundary of qiyās in this context. As a renowned, contemporary scholar of Islamic jurisprudence, Mohammad Hashim Kamali, has aptly articulated: 
Marriage differs from other transactions; business transactions are personal matters but marriage concerns the family and the social status of the parents and guardians. Hence an analogy between marriage and other transactions is unjustified. ${ }^{81}$

The ramifications may be better explained in terms of the concept of commodity. A commodity is "an article of trade or commerce", ${ }^{22}$ "an exchangeable unit of economic wealth, esp. a primary product or raw material", ${ }^{83}$ "a class of economic good" ${ }^{84}$ or "an economic good" ${ }^{85}$ Does "commodity' include other generic meaning, such as something of value, usefulness or benefit? Yes, these meanings are also listed in all the dictionaries. However, those generic ones are neither primary nor contextually relevant, because when invoking the sale analogy, the sense in which it is used is obvious.

Invoking sale analogy is invariably assigning the notion of commodity to women in this context of marital relationship. There is a related notion, property, which makes it even more problematic. A property is: "something owned or possessed", "the exclusive right to possess, enjoy, and dispose of a thing", 86 "that which a person owns; the possession or possessions of a particular owner", "goods, land, etc., considered as possessions" ${ }^{87}$

The notions of commodity and property are related because while all properties are not necessarily commodities, but all the commodities can be properties, and thus, owned. Once again, invoking sale cannot be separate from treating something as commodity and property that can be owned. By applying the sales contracts as the basis for qiyās to marriage contracts, essentially the women are commodified, i.e, reduced to commodities that can be owned and traded.

Yet, how in the world could the Muslim scholars gloss over this aspect that through such application of commercial concepts they were commodifying women? To understand this issue, one has to probe a little deeper to the human level. In reality, the orthodox or traditional scholars have not commodified just the women, but also have commodified the human being in general through their view about slavery.

The orthodox position is that Islam did not prohibit slavery, which is contrary to the essential Islamic view about fundamental human dignity. ${ }^{88}$ Slavery means treating some human beings as property that can be owned and as a commodity that can be traded, even on a contractual basis. Once anyone is reconciled with the permissibility or acceptability of slavery, it is not a far-fetched leap to commodify women and then resort to frame their rights in analogical reference to sales contracts. Given the otherwise noble, conscientious and sensitive character of the Muslim scholars, it would be unfair to argue that they were consciously overextending these qiyās-based rulings. But the reality is that they did overextend such applications and, lacking other potential explanations, due to this factor that they did uphold the permissibility of slavery - meaning, human beings can be owned and traded 
and sales contracts can be applied to them - the extension of the qiyās to marriage contract as analogical equivalent of sales contract was an easy gloss-over.

It needs to be noted, however, that human beings must be excluded from the scope of property - things that can be owned - and of the scope of commodity - that can be traded or bought and sold. Once this is recognised, the problem with the scholars' misapplication of qiyās becomes obvious. The burden of this misapplication, however, should not be placed on Islam, because Islam does uphold the fundamental human dignity and if we believe in and affirm that, then human beings cannot be owned like property and traded like a commodity.

\section{What Else Could Have Prevented this Commodification?}

As slavery and concubinage continued to be in practice, commodification was a reality. However, in the sphere of law or legal discourse, this potentially could have been prevented or at least challenged, had it not been that the Islamic legal discourse and the resulting corpus of Islamic law were developed and shaped by the exclusive domain of the male.

It is noteworthy that the qur'ānic message in regard to genders is highly egalitarian. During the time of the Prophet Muhammad as well as the Rightly-Guided Caliphs (al-khulafä' al-rāshidūn), women played a role in the society that could not be significantly distinguished from men's. There were several women personalities, such as Ayesha, who served as jurists of the highest stature and were acknowledged during that time as highly capable and leading experts in legal and religious matters. Gradually women's roles were marginalised, until, except a few areas like hadithscholarship ${ }^{89}$ they disappeared from the public view. The juristic or legal discourse then became a male-exclusive domain.

The absence of women, contrary to the experience of the earliest generations of and since the era of the Prophet Muhammad, in itself is a serious question to be addressed. However, even though the male scholars in general cannot be judged or blamed for any misogynistic bias or prejudice, quite undoubtedly qualified female input to that discourse was lacking. During the early periods since the time of the Prophet there were capable and vigilant women who corrected their male counterparts, whenever they saw anti-women biases. That voice was and generally still is absent from the Islamic legal discourse.

In general, men and women should be equal participants in the Islamic legal discourse and their presence could have then and can now prevent such commodification, whether that is an innocent gloss over or it is rooted in misogyny. The Prophet himself involved his community - male and female - in deciding the strategy to follow during the Battle of Uhud and despite the less than favourable outcome for the Muslims the consequences of the decision cannot be held to mitigate against the need to institute a process of consultation and representation nevertheless. Earlier, 
Muslim women happened to be among the participants who swore the Allegiance of Riḍaan to the Prophet; this is reason enough not to tolerate the absence of Muslim women in juristic and sharì $a h$-related matters, particularly in those deliberations that affect them.

Of course, women should be part of juristic discourse at all levels, including at the very highest level of $i j t i h \bar{a} d$. Muslims should find the absence of women a serious violation of the qur'ānic view about women being men's mutual awliy $\bar{a}$ ' (guardians). And any juristic position that deviates from this position should be regarded as deficient. In other words, any juristic view, position, opinion or fatwā involving women which emanates solely from an exclusively male club of jurists should be considered deficient by default unless proven otherwise and incontrovertibly. As far as the general juristic discourse occurs in the present that one half of the mutual awliy $\bar{a}$ ' is absent must be acknowledged. Some effort needs to be effected to remove this imbalance and deficiency gradually but surely, not out of some benevolent generosity to women, but for the benefit and wholeness of society. The revered generation of companions who accompanied the Prophet was not complete without 'A' 'ishah, Umm Salamah, and other women who acted as mentors, guides, teachers and jurists. This state of affairs should be true for all time, where, for a balanced community, let alone the notion of buying and selling each other, men and women must play their role as mutual awliyā' (guardian, protector, friend) ${ }^{90}$ of each other.

\section{Conclusions and Recommendations}

Analogical reasoning, qiyās, is one of the most common methods human beings employ in all areas of knowledge. The Islamic scholars and jurists have also utilised it extensively, and in many cases it has been practised brilliantly and effectively. However, in certain cases, especially when carried away by legalistic and literalistic tendencies, qiyās has led to conclusions and rulings that are inconsistent with the Islamic precepts, leading to its illegitimate application. This does not mean that there is a general problem with qiyās as a methodology; it remains a valid component of the jurist's toolkit to formulate laws and codes. However, it is important to note that scholars need to be humble enough to disclose and disclaim the product of such exercises as fallible. They also need to practise extreme caution in not becoming carried away when employing these tools of human reasoning. Furthermore, the discussion about qiyās is also pertinent in the context of the discourse concerning the sharī'ah in general, where it is presented as divine and immutable. Qiyās, in particular, is illustrative of the fact that there is hardly any element that is divine about it. This is so because it is an essentially human exercise in reasoning; many aspects of the shari $\bar{a}^{\prime}$ h relying on the practice of qiyās. 
AbuSulayman makes another important point about the micro-level application of qiyās to piecemeal issues without assuming a more holistic or systematic approach or perspective.

Qiyas can no longer be partial or call for an issue-by-issue approach. It has to be systematic, conceptual, abstract, and comprehensive. ${ }^{91}$

The overuse or inappropriate exercise of qiyās, especially in the search for the 'illah, delinked from hikmah (rationale or wisdom) and lacking a systematic perspective, has contributed toward the current rigidity, legalism and dysfunctional behaviour of the Muslim world. Qiyass, or analogical reasoning, will remain a valuable part of the Islamic methodology of jurisprudence come what may. However, the authoritativeness attributed toward the method and toward its products has to be brought back down to a realistically defensible level.

Once again, a law does not become Islamic because of an exercise in qiyās, which is speculative application, yielding non-definitive outcomes. Instead, a law becomes Islamic when it meets all of the following conditions:

- the formulation of the law must be rooted in the foundational sources of Islam;

- it is derived with explicit attention to the maqāssid and values of Islam, and

- the adoption and enactment of the law by the society occurs through shürā (consultation and representation).

Kamali, an eminent contemporary scholar of Islamic jurisprudence, remarks:

Wisdom and application of 'good sense', rather than a mechanical or fixed set of logical rules, is recommended in the determination of ratio decidendi. [...] But the rigidity that the Muslim jurist tried to avoid in this instance was visited upon him through the imposition of burdensome technicalities on qiyās. The correct advice in both instances is surely to avoid rigid conformity to precedent at the expense of losing sight of the broad purpose and objective of the law. ${ }^{92}$

The present generation of scholars, with women as scholars and jurists present at the table of the relevant discourse, needs to follow in the footsteps of the original scholars of Islam by disregarding their mistakes and building on their successes - theirs has been a vital contribution to the systemisation of the various Islamic codes and laws, after all. The original scholars in every epoch have approached their pertinent field of interest with the highest regard to the past generations and the contributions they made to Islamic knowledge. By the same token, they also never wavered in identifying mistakes, whenever applicable, and in turning to the Qur'ān and the legacy of the Prophet, as well as resorting to human reasoning and conscience, to offer newer or improved perspectives and articulation. 
And so is this approach applicable here. The vast treasure of knowledge and wisdom left behind by the earlier generations of brilliant and noble scholars must be respected, learned and applied, but in a forward-looking manner. The new generation of scholars must correctly discern the issues affecting the current period and endeavour to shape the future not merely through the lens of the past generation of scholars and their works, but through the lens of the Qur'ān and the Prophetic legacy. By doing so, the Muslim forebears will neither be disrespected nor will their work be discarded. Instead, following their lead is the way to ensure that they remain endeared and paid homage to. Thus, a forward-looking approach and perspective, guided by the Qur'ān and the Prophetic legacy, and enriched by the learning of the past becomes the present and future imperative. An essential foundation of this forward-looking approach has to be steadfast acknowledgement of the fundamental human dignity, which also means that human beings cannot be commodified: women or men cannot be owned and cannot be traded (bought and sold) and their rights and duties must not be framed in commercial exchanges or buy-sale type contracts.

\section{Notes}

1. Mohammad Hashim Kamali, Shariah Law: An Introduction (Oxford: Oneworld, 2008); M.N. Siddiqi, "Relevance and Need for Understanding the Essence of Religious Traditions in the Contemporary World", paper presented at the International Seminar on Inter-Civilisational Dialogue in a Globalising World, Institute of Objective Studies, New Delhi, 8-10 April 2005, available online at http://www.siddiqi.com/mns/Relevance_April2005_Delhi.htm (accessed on 8 May 2006).

2. For pertinent information and analysis of this un-Islamic and inhuman experience, see Mohammad Omar Farooq, "Rape and Hudood Ordinance: Perversions of Justice in the Name of Islam", available online at http://www.islamicity.com/articles/Articles.asp?ref=IC0612-3179 (accessed on 21 June 2007), and A. Quraishi, "Her Honor: An Islamic Critique of the Rape Laws of Pakistan from a Woman-Sensitive Perspective", Michigan Journal of International Law 18 (1997), 287-320.

3. M. Hasan, "Women's Personal Law Board", Milli Gazette [New Delhi], 16-28 February 2005; "Muslim Women Form Their Own Personal Law Board", Deccan Herald [Bangalore, India], 3 February 2005.

4. This highly critical view about the Taliban perspective of Islam should in no way be interpreted as an endorsement of any invading and occupying external force in Afghanistan.

5. There is no consensus about specifically demarcating various periods in the history of the development of Islamic law. However, there is little disagreement about the fact that by the third/ fourth hijrī century orthodoxy had taken shape. See Wael Hallaq, The Origins and Evolution of Islamic Law (Cambridge: Cambridge University Press, 2005), 1.

6. A. AbuSulayman, The Islamic Theory of International Relations: New Directions for Islamic Methodology and Thought (Herndon VA: International Institute of Islamic Thought, 1987), 2. Unless mentioned otherwise, all emphases are from the author of this article.

7. A. Hasan, The Doctrine of Ijma: A Study of the Juridical Principle of Consensus (New Delhi: Kitab Bhavan, 2003), 21.

8. Mohammad Omar Farooq, Toward Our Reformation: From Legalism to Value-Oriented Islamic Law and Jurisprudence (Herndon VA: International Institute of Islamic Thought, 2011, forthcoming).

ICR 3.1 Produced and distributed by Pluto Journals ICR.plutojournals.org 
9. A. Hasan, Analogical Reasoning in Islamic Jurisprudence: A Study of the Juridical Principle of Qiyas (Islamabad: Islamic Research Institute, 1986), 424.

10. Being self-critical generally means being critical of oneself. However, the sense in which self-critical perspective is used here refers to a positive approach where before shifting blames to others or adopting fault-finding attitude focused on others, one should begin any scrutiny with oneself and continuously be on guard about one's own weakness or shortcoming. This does not mean always finding or trying to find fault with oneself. Even when we are conscious about the possibility that we can err or have shortcoming is part of a self-critical approach.

11. Yusuf al-Qaradawi, "The Lawful and the Prohibited in Islam", undated, available online at http:// www.witness-pioneer.org/vil/Books/Q_LP/Int.htm (accessed 17 May 2007), 14-15.

12. M. Muslehuddin, Philosophy of Islamic Law and the Orientalists (New Delhi: Taj Company, 1986), 140.

13. AbuSulayman, The Islamic Theory, 66 .

14. Majid Khadduri (tr. with introduction and notes), Al-Shafi'is Risala: Treatise on the Foundations of Islamic Jurisprudence (Cambridge, England: Islamic Texts Society, 1987, 2nd ed.), 78.

15. Hasan, Analogical Reasoning, 425, quoting Ibn Quțaybah, Ta'wìl mukhtalif al-hadìth (Cairo: Mațba 'ah Kurdistān al- 'Ilmiyyah, 1326AH/1908), 65.

16. Muslehuddin, Philosophy, 136.

17. Farooq, Toward.

18. Kamali, Shariah Law, 128.

19. Hasan, Analogical Reasoning, Chapter Three.

20. A. Hasan (tr.), Sunan Abū Dawud, 3 vols (New Delhi: Kitab Bhavan, 1990), vol. 3, no. 3,585.

21. Hasan, Analogical Reasoning, 454, referring to Ibn Ḥazm's Mulakhkhaș ibtāal al-qiyās wa 'l-ra'y (Cairo: Maṭba 'ah Jāmi ah Dimashq, 1960), 14.

22. M.M. Khan (tr.), Sahīh al-Bukhārī, 9 vols (Medina: Mediana University, n.d.), "Book of Holding Fast to the Qur'an and Sunnah", Chapter 7, "Bāb mā yudhkaru min dhamm al-ra'y wa takalluf al-qiyās", 9:305, and Chapter 8, "Wa lam yaqul bi ra'y wa lā bi-qiyās", 9:307.

23. "It has been aptly argued that the headings of the various chapters of the Sahih constitutes the fiqh of al-Bukhārī" (M.Z. Siddiqi, Hadith Literature: Its Origin, Development and Special Features (Cambridge, England: Islamic Texts Society, 1993), 57). An alternative view is that the chapter titles in al-Bukhārī are not necessarily his own personal opinion but what he regarded as the prevalent view.

24. Muslehuddin, Philosophy, 137.

25. Hasan, The Doctrine, 130.

26. Muslehuddin, Philosophy, 148.

27. Ibid., 137.

28. Ibid., 140

29. Hasan, Analogical Reasoning, 12.

30. N. Shehaby, "IIlla and Qiyas in Early Islamic Legal Theory”, Journal of the American Oriental Society 102, no. 1 (January-March 1982), 27-46; M. Fadel, book review of Analytical Reasoning in Islamic Jurisprudence: A Study of Juridical Principle of Qiyas by Ahmad Hasan, in: The Journal of Law and Religion 15, no. 1-2 (2000-01), 359-62.

31. K. Dunbar, “Analogy”, undated, available online at http://www.diplomacy.edu/Language/Analogies/ default.htm (accessed on 11 March 2007).

32. Stella Vosniadou and Andrew Ortony, "Similarity and Analogical Reasoning: A Synthesis", in: Vosniadou and Andrew Ortony (eds), Similarity and Analogical Reasoning (Cambridge: Cambridge University Press, 1989), 1.

33. B. Mistler, "Masters of Analogies: The GRE Is to the MAT as Freud Is to James", undated, available online at http://old.apa.org/apags/edtrain/gre.html (accessed on 5 May 2007).

34. Kamali, Shariah Law, 265-6; Shehaby, "IIla and Qiyas", 42; U. Moghul, "Approximating Certainty in Ratiocination: How to Ascertain the "Illah (Effective Cause) in the Islamic Legal System and How to Determine the Ratio Decidendi in the Anglo-American Common Law", Journal of Islamic 
Law 4 (Fall-Winter 1999), 19; Hasan, Analogical Reasoning, 2, referring to al-Ghazālī, Maqāṣid al-falāsifah.

35. Hasan, Analogical Reasoning, 128. The dates in this quote were given in AH. For the sake of consistency throughout this article those have been substituted with CE.

36. S. Alauya, Fundamentals of Islamic Jurisprudence (Manila: Rex Book Store, 1999), 37.

37. H.A. Al-Ati, The Family Structure in Islam (Indianapolis IN: American Trust Publications, 1977), 56.

38. Ibid., 59-63.

39. Ziba Mir-Hossini, "Tamkin: Stories from a Family Court in Iran", in: Donna Bowen and Evelyn Early (eds), Everyday Life in the Muslim Middle East (Bloomington IN: Indiana University Press, 2002), 137

40. Al-Ati, The Family, 64-5.

41. Ibid., 67.

42. Ibid., 68-9.

43. Ibid., 68 .

44. Ibid.

45. Meaning, dowry (mahr).

46. C. Hamilton (tr. with introduction and notes), Al-Hedaya by Al-Marghinani (Karachi: n.p., 1989, 2nd ed.), 150 .

47. Ibid.

48. Ibid., 151

49. Ibid., 92.

50. Al-Qayrawānī (d. 996 CE), Section 31.13a

51. Ibid., Section 32.3.

52. Ibid., Section 32.4e.

53. Ibn Al-Naqib, Reliance of the Traveller: The Classic Manual of Islamic Sacred Law (Umdat Al-Salik), tr. Nuh Ha Mim Keller (Beltsville MD: Amana Publications, 1997), m3.2.

54. Ibn Qudāmah, 8:173-6, quoted in Oussama Arabi, Studies in Modern Islamic Law and Jurisprudence (Leiden: Brill, 2001), 181

55. "Refutations of the validity of qiyas are to be found in Imami Shi'i collections of reports (akhbar), all available Shi'i works of usul al-figh, polemics against Sunni thought and not infrequently in works of furu' al-fiqh" (Robert Gleave, "Imami Shi'i Refulations of Qiyas", in: Bernard Weiss (ed.), Studies in Islamic Legal Theory (Leiden: Brill, 2002), 267). Apparently, the ușülīs, the now dominant group of the Twelver Shi ites, do accept the validity of qiyās. "In contrast to most scholars of the rival camp, the usuli jurists practiced ijtihad by employing analogical deduction (qiyas) in order to infer opinions from the text of the Qur'an and the hadith" (Abbas Amanat, "From ijtihad to wilayat-i-faqih: The Evolution of the Shiite Legal Authority to Political Power", in: Abbas Amanat and Frank Griffel (eds), Shari'a: Islamic Law in the Contemporary Context (Palo Alto CA: Stanford University Press, 2007), 124).

56. Muhammad Khalid Masud, "The Award of Mata' in the Early Muslim Courts", in: Muhammad Khalid Masud, R. Peters and David Powers (eds), Dispensing Justice in Islam: Qadis and their Judgments (Leiden: Brill, 2006), 360.

57. Al-Ati, The Family, 69.

58. Ibid., 70.

59. Hamilton (tr.), Al-Hedaya, 401-2.

60. B.M. Dayal (tr. with introduction and notes), Durr-ul-Mukhtar by Al-Haskafi (New Delhi: Kitab Bhavan, 1992), 322.

61. Hamilton (tr.), Al-Hedaya, 402 .

62. Ibid., 392.

63. Dayal (tr.), Durr-ul-Mukhtar, 316

64. Hamilton (tr.), Al-Hedaya, 396.

65. Al-Ati, The Family, 151.

ICR 3.1 Produced and distributed by Pluto Journals ICR.plutojournals.org 
66. Ibid., 152

67. Ibid.

68. Moghul, "Approximating", 15-16.

69. Al-Ati, The Family, 155.

70. Ibid., 154-5.

71. Hamilton (tr.), Al-Hedaya, 392.

72. J. Cowan (ed.), Arabic-English Dictionary: The Hans Wehr Dictionary of Modern Written Arabic (Ithaca NY: Spoken Language Services, Inc., 1976), 153.

73. Dayal (tr.), Durr-ul-Mukhtar, 316.

74. Azizah Al-Hibri, "The Nature of Islamic Marriage: Sacramental, Covenantal, or Contractual?" in: John Witte and Eliza Ellison (eds), Covenant Marriage in Comparative Perspective (Wm. B. Eerdmans Publishing, 2005), 185.

75. Ahmad ibn Muhammad Tahawi, Functions of Documents in Islamic Law: The Chapters on Sales from Tahawi's Kitab al-Shurut al-Kabir, tr., ed. Jeanette Wakin (Albany NY: SUNY Press, 1972), 38.

76. A.H. Siddiqi (tr. with introduction and notes), Șahịh Muslim, 4 vols (Lahore: Sh. Muhammad Ashraf, 1982), no. 3,465.

77. Cowan (ed.), Arabic-English Dictionary, 890.

78. Abdur Rahman I. Doi, "Women in the Qur'an and the Sunnah", undated, available online at http:// islamic-world.net/sister/in_the_quran.htm (accessed on 6 October 2010).

79. Siddiqi (tr.), Sahịh Muslim, \#3,465.

80. Sangh Mittra and Bachchan Kumar, Encyclopaedia of Women in South Asia: Afghanistan (Delhi: Kalpaz Publishing, 2004), 99.

81. Mohammad Hashim Kamali, Principles of Islamic Jurisprudence (Cambridge: Islamic Texts Society, 2003, 3rd ed.), 188.

82. http://www.Dictionary.com

83. World English Dictionary, http://dictionary.reference.com/browse/commodity

84. Legal Dictionary, http://dictionary.reference.com/browse/commodity

85. http://www.merriam-webster.com/dictionary/

86. Ibid.

87. http://www.Dictionary.com

88. Mohammad Omar Farooq, "Fundamental Human Dignity and The Mathematics of Slavery", available online at http://www.globalwebpost.com/farooqm/writings/islamic/slavery_math.html (accessed on 21 June 2007).

89. Idem, "Women Scholars of Islam: They Must Bloom Again", Message International 28, no. 8-9 (August-September 2003), 27-33.

90. Qur'ān 9:71.

91. AbuSulayman, The Islamic Theory, 84.

92. Kamali, Principles, 301. 